\title{
Pemberdayaan masyarakat melalui pelatihan pembuatan pupuk organik menggunakan tabung fermentasi berbasis teknologi di Desa Ulugalung Kabupaten Bantaeng
}

\author{
Muhammad Nur Jumadil, Widya Astuti Rinduwati, Ainun Septia Nengsi \\ Ramli, Andi Izdihar Sricendani, Andi Maulidyisah Ekasalim, \& Nunik \\ Lestari (iD) *
}

\author{
Fakultas Teknik, Universitas Negeri Makassar, Indonesia \\ *nunik.lestari@unm.ac.id
}

\begin{abstract}
Ulugalung Village, which is located in Bantaeng Regency, often experiences fertilizer scarcity problems. On the other hand, natural resources in the form of rice straw are very abundant in this village. However, the community does not have adequate knowledge and skills to process rice straw into organic fertilizer. Therefore, training is needed to help the community overcome these problems. The purpose of this community service activity is to improve the knowledge and skills of the community in Ulugalung Village in making organic fertilizer by utilizing a technology-based fermentation tube composter. This activity combines the lecture method in delivering training materials, as well as a demonstration method to provide skills and experience in making organic fertilizers made from rice straw waste. This activity involved academics, the government, the Pullauweng farmer group, and the Ulugalung villagers. The results of this activity show that the level of achievement of the goals of this service activity was very good, with an increase in the knowledge and skills of participants by $87.7 \%$. This percentage indicates that participants have understood the knowledge related to straw composting and could practice the process of composting rice straw using technology-based fermentation tubes independently.
\end{abstract}

\begin{abstract}
Abstrak Desa Ulugalung yang terletak di Kabupaten Bantaeng sering kali mengalami masalah kelangkaan pupuk. Di lain sisi, sumber daya alam berupa jerami padi sangat melimpah di desa ini. Akan tetapi, masyarakat tidak memiliki pengetahuan dan keterampilan yang memadai untuk mengolah jerami padi menjadi pupuk organik. Oleh karena itu diperlukan pelatihan untuk membantu masyarakat mengatasi masalah tersebut. Tujuan kegiatan pengabdian kepada masyarakat ini adalah untuk meningkatkan pengetahuan dan keterampilan masyarakat di Desa Ulugalung dalam membuat pupuk organik dengan memanfaatkan komposter tabung fermentasi berbasis teknologi. Kegiatan ini menggabungkan metode ceramah dalam menyampaikan materi pelatihan, serta metode demonstrasi untuk memberikan keterampilan dan pengalaman dalam pembuatan pupuk organik berbahan dasar limbah jerami padi. Kegiatan ini melibatkan akademisi, pemerintah, kelompok tani Pullauweng, serta masyarakat Desa Ulugalung. Hasil dari kegiatan ini menunjukkan tingkat ketercapaian tujuan dari kegiatan pengabdian ini sangat baik, dengan peningkatan pengetahuan dan keterampilan peserta sebesar $87.7 \%$. Persentase ini menunjukkan bahwa peserta memahami pengetahuan terkait pengomposan jerami dan dapat mempraktikkan proses pengomposan jerami padi menggunakan tabung fermentasi berbasis teknologi secara mandiri.
\end{abstract}

Keywords: organic fertilizer; composter; fermentation tube; rice straw; farmer; training

\section{OOPEN ACCESS}

Citation: Jumadil, M. N., W. A. Rinduwati., A. S N. Ramli., A. I. Sricendani., A. M. Ekasalim., N. Lestari. (2021). Pemberdayaan masyarakat melalui pelatihan pembuatan pupuk organik menggunakan tabung fermentasi berbasis teknologi di Desa Ulugalung Kabupaten Bantaeng. Riau Journal of Empowerment, 4(2), 119-128. https://doi.org/10.31258/raje.4.2.119 $\underline{128}$

Received: 2021-08-03 Revised: 2021-09-20 Accepted: 2021-10-01

Funding: Kementerian Pendidikan, Kebudayaan, Riset, dan Teknologi Republik Indonesia

Language: Bahasa Indonesia (id) ISSN 2623-1549 (online), 2654-4520 (print)

(c) 2021 Muhammad Nur Jumadil, Widya Astuti Rinduwati, Ainun Septia Nengsi Ramli, Andi Izdihar Sricendani, Andi Maulidyisah Ekasalim, \& Nunik Lestari. Author(s) retain the copyright of article published in this journal, with first publication rights granted to Riau Journal of Empowerment. The article is licenced under Creative Commons Attribution 4.0 Internationa License. This license permits unrestricted use, distribution, and reproduction in any medium, provided the original author and source are credited. 


\section{PENDAHULUAN}

Degradasi yang terjadi pada sebagian besar lahan persawahan merupakan salah satu penyebab menurunnya produktivitas sawah di Indonesia. Banyak faktor yang dapat menyebabkan terjadinya hal tersebut, beberapa diantaranya adalah seperti penggunakaan pestisida dan pupuk anorganik (Sukainah et al, 2020). Penggunaan pestisida dan pupuk anorganik tersebut cenderung tidak aman dan berbahaya bagi lingkungan (Mahyuni, 2015). Terkhusus untuk penggunaan pupuk anorganik, sampai saat ini pengaplikasiannya belum memperhatikan kebutuhan tanaman secara spesifik. Aplikasi pupuk anorganik di lahan cenderung berlebihan sehingga memberi efek negatif seperti pemborosan biaya, inefisiensi pupuk, pencemaran lahan dan badan air akibat residu pupuk, serta terganggunya keseimbangan hara dan bahan organik di dalam tanah (Budaraga dan Murnita, 2019).

Keseimbangan hara dan bahan organik di dalam tanah merupakan salah satu faktor penting untuk menunjang pertumbuhan tanaman sehingga menghasilkan produktivitas yang tinggi. Akan tetapi beberapa data menunjukkan bahwa saat ini sekitar 65\% dari 5.000.000 ha lahan sawah irigasi memiliki kandungan oganik dalam tanah yang kurang dari 2\% (Badan Litbang Departemen Pertanian, 2007). Jumlah ini cukup rendah jika dibandingkan dengan lahan normal yang biasanya memiliki kandungan organik tanah minimal 3\% (Simanungkalit et al, 2006).

Permasalahan mengenai degradasi lahan persawahan juga terjadi di Desa Ulugalung. Desa Ulugalung merupakan salah satu desa di Kabupaten Bantaeng Sulawesi Selatan, dengan luas lahan persawahan sekitar 100 ha serta lahan perkebunan sekitar 90 ha. Potensi alam yang mendukung serta lahan persawahan yang relatif luas tersebut menjadikan pekerjaan utama masyarakat di Desa Ulugalung adalah bertani. Dalam proses budidaya tanaman padi, masyarakat petani di Desa Ulugalung sangat tergantung pada penggunaan pupuk anorganik atau pupuk kimia sintetik. Penggunaan pupuk anorganik tersebut telah dilakukan oleh petani di Desa Ulugalung secara turun-temurun. Akan tetapi ketersediaan pupuk anorganik di Kabupaten Bantaeng terkhusus Desa Ulugalung sering kali terjadi kelangkaan dan kekurangan pasokan.

Kondisi ini tentu sangat mengganggu kegiatan usaha tani yang dilakukan oleh masyarakat disana. Apalagi petani disana sangat membutuhkan pupuk anorganik tersebut untuk dapat memaksimalkan pertumbuhan dan hasil tanaman padi yang dibudidayakannya. Kebutuhan pupuk anorganik menjadi hal yang sangat vital untuk menunjang pemenuhan hara bagi tanaman, karena petani tidak dapat hanya mengandalkan lahan persawahan yang mereka miliki yang sudah semakin terdegradasi kualitasnya.

Penggunaan pupuk anorganik memang dapat meningkatkan kandungan unsur hara makro dan mikro pada tanah, namun tentu saja penggunaannya dapat menimbulkan efek samping negatif (Kaya, 2013). Pupuk urea yang digunakan dengan dosis yang berlebihan dapat menyebabkan pencemaran nitrat pada tanah. Efektivitas penggunaan pupuk urea tidak bertahan lama karena penggunaan pupuk kimia secara terus-menerus dapat menyebabkan perubahan struktur tanah, pemadatan, kandungan unsur hara dalam tanah menurun, serta pencermaran tanah (Triyono, 2013). Sehingga untuk mengatasi permasalahan degradasi kualitas lahan persawahan dan untuk mengatasi kelangkaan ketersediaan pupuk anorganik di Kabupaten Bantaeng, khususnya di Desa Ulugalung, maka diperlukan sebuah terobosan dalam usaha penyediaan pupuk organik yang dapat dilakukan secara mandiri oleh masyarakat setempat. 
Hal ini sangat mungkin untuk dilakukan, mengingat Desa Ulugalung memiliki potensi lahan persawahan yang sangat luas dengan potensi limbah jerami padi yang sangat besar. Selama ini limbah jerami padi di Desa Ulugalung hanya sebagian kecil yang telah dimanfaatkan masyarakat sebagai pakan ternak, sementara sisanya hanya dibakar. Hal ini tentu

Jumadil et al. sangat disayangkan, mengingat persentase jerami yang belum termanfaatkan (langsung dibakar) lebih dominan dibandingkan dengan yang telah dimanfaatkan dengan baik. Di lain sisi, limbah jerami padi memiliki potensi besar untuk dijadikan pupuk organik yang kemudian dapat digunakan untuk menunjang kebutuhan unsur hara tanaman padi, memperbaiki kualitas lahan (Pranata dan Kurniasih, 2019), meningkatkan bahan organik tanah (Pane et al, 2014), serta menjadi jawaban terhadap masalah keterbatasan ketersediaan pupuk anorganik disana. Pengembalian jerami padi ke tanah dalam bentuk pupuk organik juga berarti mengembalikan sebagian unsur hara serta membantu menjaga ketersediaan hara dalam tanah (Muliarta, 2020).

Pembuatan pupuk organik dapat dioptimalkan prosesnya dengan melibatkan bantuan alat dan teknologi, salah satunya adalah dengan menggunakan komposter tabung fermentasi berbasis teknologi. Komposter ini dilengkapi dengan sistem kontrol pengaturan kelembaban dan sistem monitoring faktor-faktor pengomposan, seperti suhu, kelembaban relatif, dan $\mathrm{pH}$. Dengan penerapan teknologi dalam proses pengomposan, diharapkan dapat mempercepat proses terbentuknya pupuk organik dibandingkan pengomposan dengan cara konvensional, serta memudahkan petani dalam pemantauan proses pengomposan hingga penentuan waktu selesainya proses pengomposan.

Berdasarkan identifikasi masalah tersebut, maka dilaksanakan kegiatan pengabdian kepada masyarakat berupa pemberdayaan masyarakat melalui pelatihan pembuatan pupuk organik menggunakan tabung fermentasi berbasis teknologi. Kegiatan ini bertujuan untuk meningkatkan pengetahuan dan keterampilan masyarakat di Desa Ulugalung dalam pembuatan pupuk organik dengan memanfaatkan komposter tabung fermentasi berbasis teknologi. Melalui kegiatan ini diharapkan dapat meningkatkan pemahaman masyarakat dan mampu mengubah pola pikir masyarakat untuk beralih ke pertanian organik yang lebih ramah lingkungan, ekonomis, dan menghasilkan produk bernilai jual tinggi.

\section{METODE PENERAPAN}

Metode yang digunakan dalam kegiatan ini adalah metode ceramah dan praktik secara langsung pembuatan pupuk organik (kompos dan pupuk organik cair) menggunakan komposter tabung fermentasi berbasis teknologi. Sebelum dan sesudah kegiatan dilakukan evaluasi capaian pengetahuan dan kegiatan dengan menggunakan alat ukur ketercapaian dan pendampingan berkelanjutan terhadap petani di Desa Ulugalung, terkhusus kepada kelompok tani Pullauweng. Adapun langkah-langkah yang dilakukan dalam kegiatan ini diuraikan sebagai berikut.

\section{Langkah 1. Metode Ceramah (Materi)}

Metode ceramah dilakukan untuk menyampaikan materi yang berkaitan dengan penggunaan tabung fermentasi berbasis teknologi dalam pembuatan pupuk organik. Metode ceramah yang disampaikan oleh tim dilakukan secara bergantian. Adapun materi yang disampaikan adalah mengenai konsep pertanian organik, dampak buruk penanganan limbah pertanian yang salah, manfaat jerami, manfaat penggunaan pupuk organik, dampak buruk penggunaan pupuk anorganik, spesifikasi alat tabung fermentasi berbasis teknologi, serta cara mengaplikasikan 
alat tabung fermentasi berbasis teknologi. Penggunaan metode ceramah dikombinasikan dengan menampilkan secara langsung alat tabung fermentasi berbasis teknologi di depan masyarakat peserta pelatihan. Untuk mendukung penyampaian materi pelatihan, maka dilakukan juga pembagian buku pedoman penggunaan tabung fermentasi berbasis teknologi kepada peserta pelatihan. Selain berisi petunjuk penggunaan alat, buku pedoman ini juga berisi materi-materi yang disampaikan melalui metode ceramah.

\section{Langkah 2. Praktik Pembuatan Pupuk Organik}

Setelah penjelasan materi selesai, maka kegiatan dilanjutkan dengan melakukan praktik langsung pembuatan pupuk organik menggunakan tabung fermentasi jerami berbasis teknologi. Dengan dilakukannya praktik secara langsung, maka para peserta pelatihan diharapkan memiliki keterampilan dalam membuat pupuk organik menggunakan tabung fermentasi berbasis teknologi, serta memahami cara pengoperasian alat dan fungsi-fungsinya. Dalam kegiatan praktik ini tim melakukan demonstrasi fungsi-fungsi alat dan penggunaannya dalam pembuatan pupuk organik padat maupun cair. Proses demonstrasi dimulai dari tahap persiapan alat dan bahan, hingga pencampuran bahan yang akan dikomposkan selesai dan siap dimonitoring pada saat berada di dalam tabung fermentasi.

Pembuatan pupuk organik diadopsi dari metode yang dikembangkan pada penelitian Wahyuni dan Asngad (2017). Adapun langkah-langkah pembuatan pupuk organik menggunakan tabung fermentasi berbasis teknologi adalah dengan menyiapkan alat dan bahan yang diperlukan berupa satu paket alat tabung fermentasi berbasis teknologi, wadah sebanyak 4 buah, alat pengaduk (tongkat), jerami sebanyak $60 \mathrm{~kg}$ yang sudah dicacah dengan ukuran cacahan sekitar $10 \mathrm{~cm}$, air sebanyak $240 \mathrm{l}$, kotoran ternak sebanyak $12 \mathrm{~kg}$, terasi udang sebanyak $1,2 \mathrm{~kg}$, gula aren sebanyak 2,4 kg, dan EM4 sebanyak 2,4 1. Setelah itu dilanjutkan dengan melarutkan gula aren, terasi udang, dan kotoran ternak ke dalam air menggunakan wadah. Setelah bahan-bahan siap, maka langkah selanjutnya adalah menyalakan alat tabung fermentasi jerami berbasis teknologi dengan menghubungkan dengan arus listrik. Selanjutnya nyalakan sistem kontrol dengan menekan tombol power yang ada di bagian belakang kotak kontrol. Pada bagian layar LCD akan tampil identitas tim pengabdian dan nama alat serta 3 tahapan menu. Pada dua minggu pertama klik menu tahap 1 untuk melihat pengukuran parameter yang dikontrol berupa suhu bahan (SB), suhu udara dalam tabung (SU), kelembaban udara dalam tabung (RHU), dan kelembaban bahan (RHB). Untuk dua minggu kedua digunakan menu tahap 2 dan dua minggu ketiga digunakan menu tahap 3. Sebelum memasukkan bahan yang akan difermentasikan, terlebih dahulu buka tutup tabung. Selajutnya angkat sensor suhu Ds18b20 dan sensor soil mosture keluar dari tabung agar tidak putus ketika bahan yang akan difermentasi dimasukkan. Proses kemudian dilanjutkan dengan memasukkan jerami padi yang telah dicacah, yang diikuti dengan campuran larutan EM4 dan gula aren yang telah dilarutkan dalam wadah. Masukkan juga larutan terasi udang serta pupuk kandang. Jerami dimasukkan secara bergantian dengan campuran bahan lainnya agar campuran jerami dan bahan lainnya lebih merata dan memudahkan pengadukan. Lalu masukkan juga alat monitoring $\mathrm{pH}$ (derajat keasaman) manual dengan menancapkannya pada bahan yang akan difermentasi. Selanjutnya tutup tabung fermentasi. Pastikan komponen tabung fermentasi berbasis teknologi berfungsi dengan baik dengan menampilkan parameter yang benar sesuai pada layar LCD. Setelah dipastikan semua komponen berjalan dengan baik, proses monitoring dan controlling otomatis akan berlangsung selama 6 minggu. Selama jangka waktu tersebut masyarakat dan kelompok tani Pullauweng hanya perlu melakukan pemantauan dan 
memindahkan menu sesuai dengan waktu fermentasi. Proses pemantauan ini tetap didampingi oleh tim pengabdian.

Jumadil et

al.

\section{Langkah 3. Alat Ukur Ketercapaian}

Alat ukur ketercapaian kegiatan pengabdian kepada masyarakat ini adalah minimal terjadi peningkatan pengetahuan peserta mengenai pembuatan pupuk organik menggunakan tabung fermentasi berbasis teknologi. Peningkatan pengetahuan peserta tersebut diukur melalui pretest dan post-test. Pretest dan post-test dilaksanakan dengan cara mewawancarai peserta satu per satu terkait pertanyaan/pernyataan yang terdapat pada kuesioner. Hasil dari pretest dan post-test ini nantinya akan dibandingkan untuk melihat peningkatan pengetahuan peserta. Selain itu melalui pretest dan post-test, keberhasilan dari kegiatan ini juga dilihat dari terbentuknya kelompok tani yang mampu menghasilkan pupuk organik sendiri dengan menggunakan tabung fermentasi berbasis teknologi.

\section{Langkah 4. Pendampingan Berkelanjutan}

Pendampingan berkelanjutan dilakukan setelah selesai pelaksanaan kegiatan pelatihan. Pendampingan ini dilakukan untuk memberikan pengetahuan tambahan kepada mitra guna menunjang proses pembuatan pupuk organik selama 6 minggu, maupun menjawab kendalakendala yang dialami mitra selama proses pengomposan.

\section{HASIL DAN KETERCAPAIAN SASARAN}

Kegiatan pemberdayaan masyarakat melalui pelatihan pembuatan pupuk organik menggunakan tabung fermentasi berbasis teknologi ini telah dilaksanakan dan mendapat respon yang baik dari para peserta pelatihan. Pelatihan ini diharapkan dapat memberikan manfaat yang nyata bagi masyarakat di Desa Ulugalung, terutama dalam memberikan solusi dalam mengatasi kelangkaan pupuk anorganik, dengan memanfaatkan limbah jerami padi yang tersedia melimpah disana. Tabung fermentasi berbasis teknologi yang digunakan dalam pelatihan merupakan komposter yang dikembangkan dari inovasi hasil pemikiran Gunawan (2014), yang telah berhasil untuk mengurangi limbah jerami dan menciptakan ketersedian pupuk organik. Teknologi tersebut selanjutnya dikembangkan dan diteruskan oleh tim pengabdian untuk diperbantukan kepada masyarakat petani di Desa Ulugalung. Tabung fermentasi berbasis teknologi ini digunakan untuk mengubah limbah jerami padi di Desa Ulugalung yang selama ini belum termanfaatkan untuk menjadi pupuk organik. Tabung fermentasi berbasis teknologi yang dikembangkan oleh tim pengabdian ditampilkan pada Gambar 1 sebagai berikut. 

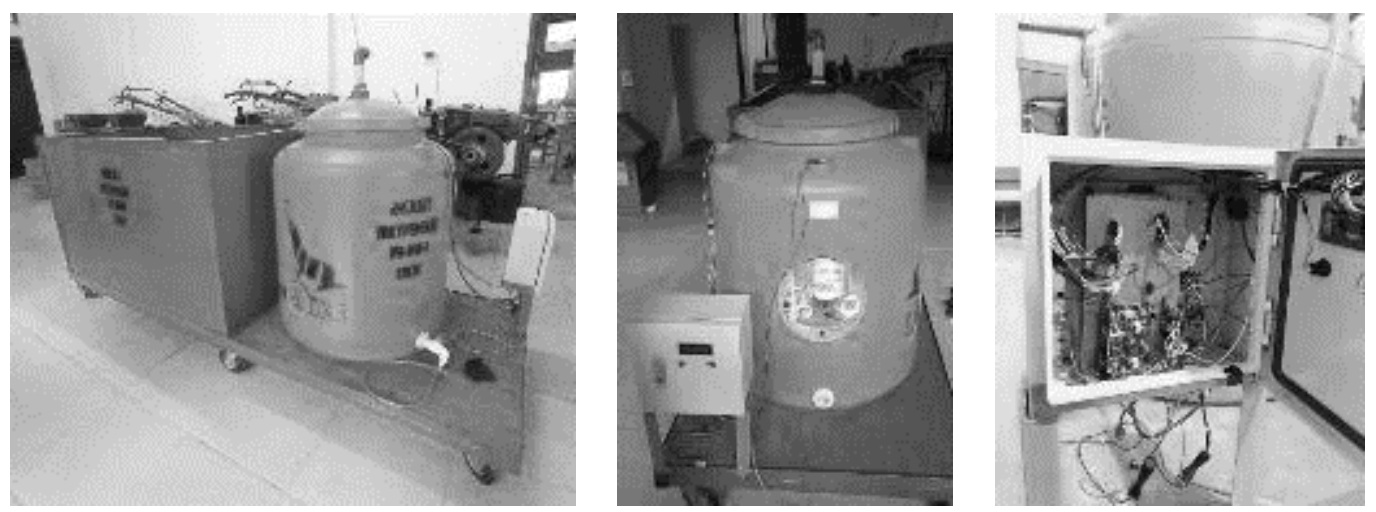

Gambar 1. Tabung fermentasi berbasis teknologi

Kegiatan pelatihan ini melibatkan masyarakat Desa Ulugalung yang tergabung dalam kelompok tani Pullauweng sebanyak 17 orang, perangkat Desa Ulugalung sebanyak 2 orang, dan tim pengabdian sebanyak 6 orang. Peserta pelatihan umumnya berjenis kelamin laki-laki dengan rentang usia 35-64 tahun. Selama kegiatan pelatihan berlangsung, peserta menunjukkan semangat dan antusiasme terhadap penyampaian materi dan demonstrasi alat serta pembuatan pupuk organik yang dilakukan, seperti ditampilkan pada Gambar 2 dan 3. Semangat dan antusiasme peserta dilihat dari fokus dan perhatian peserta saat tim pengabdian menyampaikan materi pelatihan, serta keaktifannya dalam mengajukan pertanyaan tentang materi pelatihan maupun terkait dengan praktik pembuatan pupuk organik. Keaktifan peserta saat kegiatan pelatihan juga terlihat dari partisipasi mereka secara langsung dalam proses demonstrasi penggunaan alat dan pembuatan pupuk organik. Respon positif peserta juga terlihat dari kegiatan pendampingan dan monitoring yang dilakukan oleh tim pengabdian setelah kegiatan pelatihan berakhir, dimana peserta pelatihan tetap melakukan pemantauan dan memberikan laporan terhadap proses pengomposan jerami padi yang terus mereka lakukan secara berkala hingga pupuk organik siap dipanen.
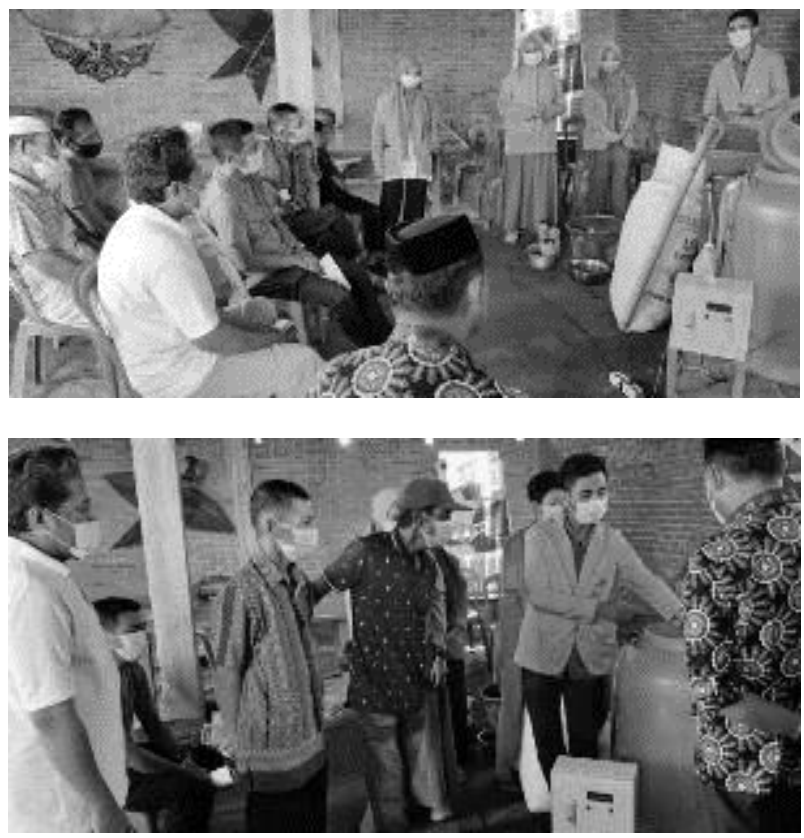

Gambar 2. Penyampaian materi yang berkaitan dengan tema kegiatan 

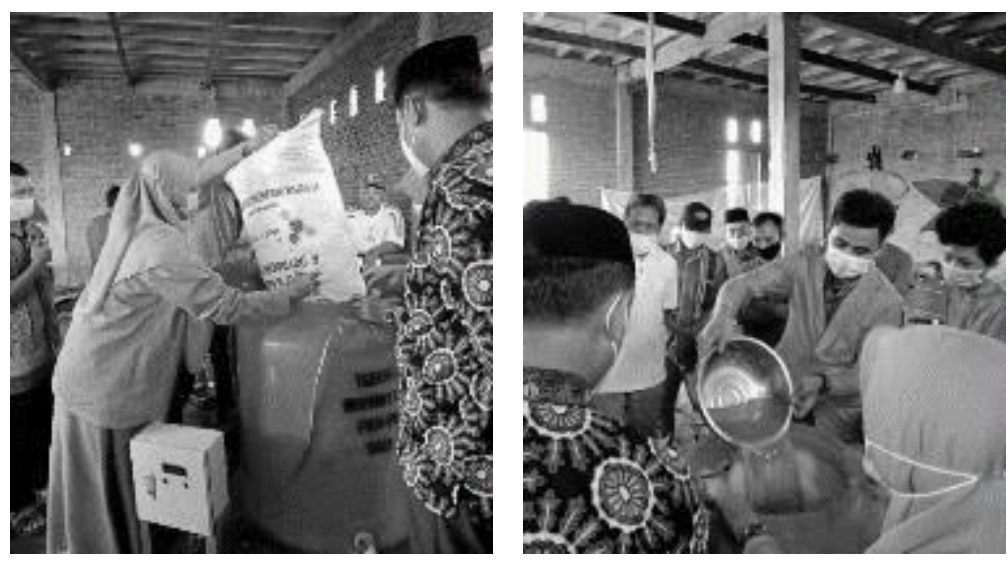

Jumadil et

al.

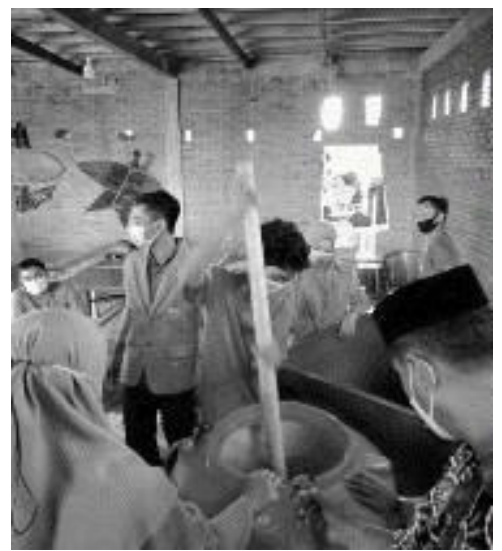

Gambar 3. Proses demonstrasi pembuatan pupuk organik menggunakan tabung fermentasi

Tingkat pemahaman dan pengetahuan peserta mengenai tema pelatihan diobsevasi sebelum dan sesudah pelatihan melalui pretest dan post-test. Hasil observasi sebelum dan sesudah pelaksanaan kegiatan ini selanjutnya dibandingkan dan dianalisis untuk melihat peningkatan pengetahuan yang diperoleh peserta dari kegiatan pelatihan ini. Perbandingan rerata nilai pretest dan post-test dari kegiatan pelatihan ini ditampilkan pada Gambar 4. Dari Gambar 4 terlihat bahwa terjadi peningkatan yang signifikan pada pengetahuan dan keterampilan peserta setelah pelaksanaan kegiatan pelatihan. Peningkatan ini diindikasikan dari peningkatan rerata nilai pretest yang semula adalah 45.44, kemudian meningkat menjadi 87.65 setelah peserta menjalani kegiatan pelatihan. Hasil ini tergolong sangat memuaskan, mengingat standar keberhasilan pelatihan ini tercapai jika peningkatan pengetahuan dan keterampilan dari nilai post-test telah mencapai nilai minimal 70 .

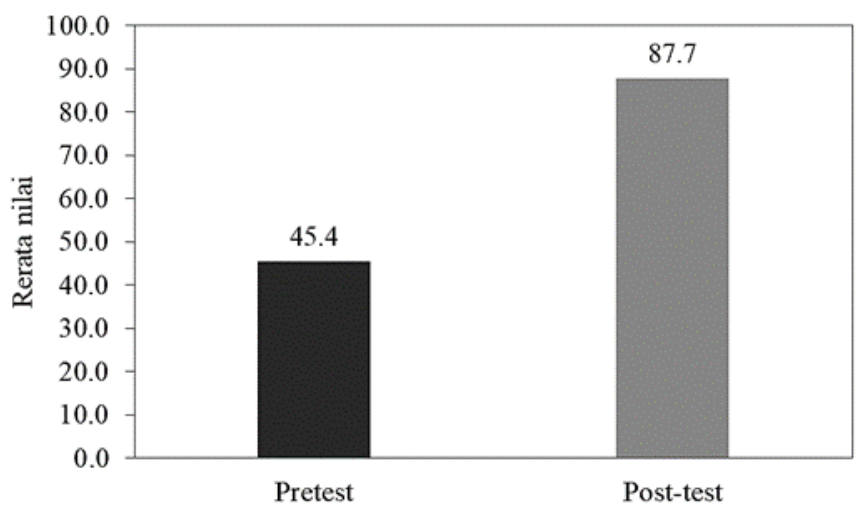

Gambar 4. Perbandingan rerata nilai pretest dan post-test dari kegiatan pelatihan 
Jika pengetahuan peserta dianalisis per tiap pertanyaan kuesioner, maka perbandingan hasilnya terlihat seperti pada Gambar 5. Hasil post-test menunjukkan bahwa terjadi peningkatan pengetahuan dasar mengenai dampak buruk pembakaran jerami yang sering dilakukan oleh petani, dari semula nilai pretest sebesar 63.3 kemudian nilai post-test naik menjadi 82.3, atau meningkat sebesar 23.1\%. Pengetahuan dasar tentang manfaat jerami padi meningkat, dari semula nilai pretest sebesar 66.3 kemudian nilai post-test naik menjadi 95.5, atau meningkat sebesar $30.6 \%$. Pengetahuan dasar tentang sistem pertanian organik meningkat, dari semula nilai pretest sebesar 54.5 kemudian nilai post-test meningkat menjadi 91.3 , atau meningkat sebesar $40.3 \%$. Pengetahuan dasar tentang cara mengolah jerami menjadi pupuk organik baik secara aerob maupun anaerob meningkat, dari semula nilai pretest sebesar 33.8 kemudian nilai post-test meningkat menjadi 97, atau meningkat sebesar $65.2 \%$. Pengetahuan dasar tentang manfaat dan cara kerja tabung fermentasi berbasis teknologi meningkat, dari semula nilai pretest sebesar 39.8 kemudian nilai post-test meningkat menjadi 89.8, atau meningkat sebesar 55.7\%. Pengetahuan dasar tentang cara membuat pupuk organik menggunakan tabung fermentasi berbasis teknologi meningkat, dari semula nilai pretest sebesar 36.8 kemudian nilai post-test meningkat menjadi 82.5, atau meningkat sebesar 55.5\%. Dan yang terakhir pengetahuan dasar tentang cara pengaplikasian pupuk organik pada tanaman juga meningkat, dari semula nilai pretest sebesar 39.8 kemudian nilai post-test meningkat menjadi 92.8, atau meningkat sebesar $57.1 \%$.

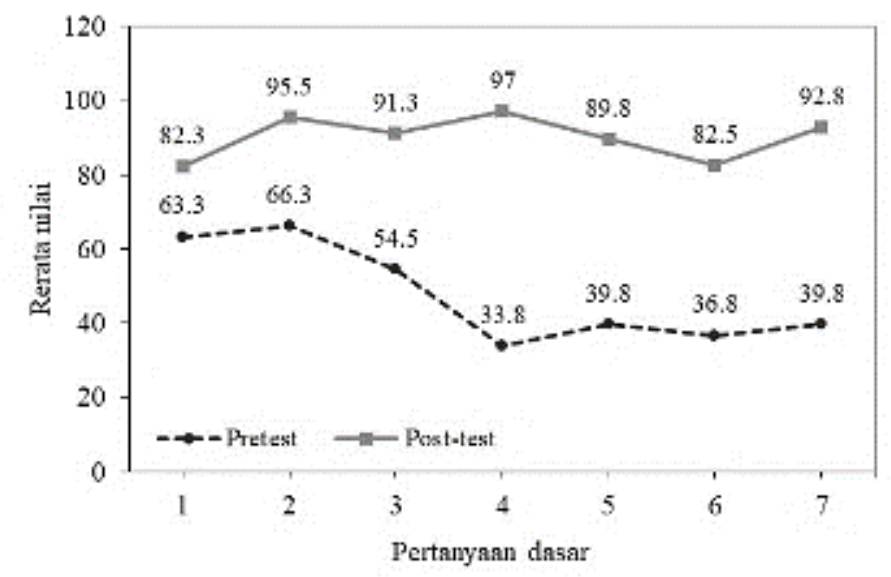

Gambar 5. Hasil tes kemampuan dasar peserta pelatihan untuk masing-masing pertanyaan dasar

Pada beberapa pertanyaan tertentu nilai pretest peserta sudah cukup lumayan memadai, seperti pada pertanyaan tentang dampak buruk pembakaran jerami, manfaat jerami, dan sistem pertanian organik. Hal ini disebabkan karena informasi terkait pertanyaan-pertanyaan tersebut sebelumnya sudah pernah didengar oleh petani dari kegiatan penyuluhan yang diadakan oleh Dinas Pertanian Kabupaten Bantaeng. Sedangkan untuk informasi spesifik terkait tabung fermentasi berbasis teknologi masih awam bagi peserta. Beberapa peserta yang dapat menjawab pertanyaan terkait tabung fermentasi sebelumnya telah sempat melakukan komunikasi dengan angggota tim pengabdian untuk membicarakan dan menyusun rencana kegiatan pelatihan.

Setelah kegiatan pelatihan ini berakhir, selanjutnya tim pengabdian melakukan pendampingan kepada mitra/peserta pelatihan sebelumnya. Kegiatan pendampingan ini dilakukan untuk membantu mitra dalam memonitoring proses pengomposan, juga untuk menjawab pertanyaan-pertanyaan yang berhubungan dengan alat tabung fermentasi maupun hal-hal terkait lainnya. Pendampingan mitra ini dilakukan secara daring untuk membatasi 
kegiatan yang berpotensi menimbulkan kerumunan di tengah pandemi Covid-19. Hal yang rutin dilakukan saat pendampingan adalah pelaporan perkembangan proses pengomposan oleh mitra setiap seminggu sekali melalui video call ataupun aplikasi pesan Whatsapp, serta peninjauan kemajuan proses tersebut oleh tim pengabdi.

Jumadil et

al.

\section{7}

Secara keseluruhan tingkat ketercapaian tujuan dari kegiatan pengabdian ini sangat baik, dengan peningkatan pengetahuan dan keterampilan peserta sebesar $87.7 \%$. Persentase ini menunjukkan bahwa peserta memahami pengetahuan terkait pengomposan jerami dan dapat mempraktikkan proses pengomposan jerami padi menggunakan tabung fermentasi berbasis teknologi secara mandiri. Dengan berakhirnya kegiatan ini diharapkan mitra dapat terus mengaplikasikan dan mengembangkan keterampilan tersebut, sehingga dapat mendukung penyediaan pupuk untuk kegiatan usaha tani yang mereka lakukan. Dengan mengalihkan penggunaan pupuk anorganik ke pupuk organik atau campuran penggunaan pupuk organik dan anorganik, maka diharapkan dapat memperbaiki kualitas lahan persawahan, serta dapat menghemat biaya usaha tani dari sisi pembelian pupuk. Selain itu, kegiatan pengomposan jerami padi ini dapat menjadi bentuk peluang usaha baru, mengingat permintaan pupuk organik di kalangan penghobi tanaman hias sangat tinggi di masa pandemi Covid-19 seperti saat ini.

\section{KESIMPULAN}

Kegiatan pemberdayaan masyarakat melalui pelatihan pembuatan pupuk organik menggunakan tabung fermentasi berbasis teknologi di Desa Ulugalung Kabupaten Bantaeng telah berhasil meningkatkan pengetahuan dan keterampilan peserta. Hal ini diindikasikan dengan ketercapaian peningkatan pengetahuan dan keterampilan dalam pembuatan pupuk organik sebesar $87.7 \%$, dibandingkan dengan persentase pengetahuan dan keterampilan awal yang hanya sebesar $45.4 \%$. Teknik pembuatan pupuk organik yang dipelajari dan dipraktikkan meliputi pembuatan pupuk organik baik secara aerob maupun anaerob dengan menggunakan alat tabung fermentasi berbasis teknologi dan perangkat pendukungnya. Peserta pelatihan juga telah memahami dan menyadari besarnya manfaat dari limbah jerami padi yang selama ini hanya dibakar begitu saja setelah kegiatan panen berakhir, dan mulai memanfaatkannya sebagai bahan dasar dalam pembuatan pupuk organik. Perubahan kebiasaan dan pola pikir masyarakat ini merupakan suatu awal yang baik, hingga nantinya masyarakat dapat terus mengembangkan usahanya tersebut, agar secara tidak langsung dapat menjadi solusi atas kelangkaan ketersediaan pupuk anorganik di Desa Ulugalung Kabupaten Bantaeng.

\section{UCAPAN TERIMA KASIH}

Kegiatan pengabdian kepada masyarakat ini merupakan bagian dari pelaksanaan Program Kreativitas Mahasiswa Penerapan Ilmu Pengetahuan dan Teknologi (PKM-PI) yang didanai oleh Direktorat Jenderal Pendidikan Tinggi (Dirjen Dikti) Kementerian Pendidikan, Kebudayaan, Riset, dan Teknologi (Kemendikbud-Ristek). Kami selaku tim pengabdian PKM-PI Universitas Negeri Makassar (UNM), mengucapkan terima kasih kepada Dirjen Dikti Kemendikbud-Ristek yang telah memberikan bantuan dana hibah sehingga kegiatan ini dapat terlaksana dengan baik. Kami juga mengucapkan terima kasih kepada Kepala Desa Ulugalung Kabupaten Bantaeng yang telah memberikan izin dan bantuan dalam pelaksanaan kegiatan, dan juga kepada kelompok tani Pullauweng yang telah bekerjasama dengan baik. 


\section{Daftar Pustaka}

1. Budaraga, I. K., \& Murnita, E. A. (2019). Penyuluhan Manfaat Penerapan Pertanian Organik di Kelompok Tani Kampung Apar Nagari Se Buluh Kecamatan Batang Anai Kabupaten Padang Pariaman [Conference presentation]. Seminar Nasional Sosial Ekonomi. https://www.researchgate.net/profile/OkkeRosmaladewi/publication/342233863_prosiding_semnas_sosek_2019_final_1/links/5eea013b29 9bf1faac5cd404/prosiding-semnas-sosek-2019-final-1.pdf\#page=100

2. Balai Penelitian dan Pengembangan Pertanian. (2007). Jerami Padi: Pengelolaan dan Pemanfaatan. Bogor. https://www.litbang.pertanian.go.id/download/2/

3. Gunawan, G., Maarif, M. S., \& Arkeman, Y. (2014). Inovasi tabung produksi pupuk cair dari jerami berbasis fermentasi dengan pendekatan value graph. Jurnal Teknik Industri, 4(1), 31-37. http://dx.doi.org/10.25105/jti.v4i1.1560

4. Kaya, E. (2013). Pengaruh kompos jerami dan pupuk NPK terhadap N-tersedia tanah, serapan-N, pertumbuhan, dan hasil padi sawah (Oryza Sativa L). Agrologia, 2(1), 43-50. http://dx.doi.org/10.30598/a.v2i1.277

5. Mahyuni, E. L. (2015). Faktor risiko dalam penggunaan pestisida pada petani di Berastagi Kabupaten Karo 2014. Kes Mas: Jurnal Fakultas Kesehatan Masyarakat Universitas Ahmad Daulan, 9(1), 79-89. http://dx.doi.org/10.12928/kesmas.v9i1.1554

6. Muliarta, I. N. (2020). Pemanfaatan kompos jerami padi guna memperbaiki kesuburan tanah dan hasil padi. Rona Teknik Pertanian, 13(2), 59-70. http://202.4.186.66/RTP/article/view/17302/13133

7. Pane, M. A., Damanik, M. M. B., \& Sitorus, B. (2014). Pemberian bahan organik kompos jerami padi dan abu sekam padi dalam memperbaiki sifat kimian tanah ultisol serta pertumbuhan tanaman jagung. Jurnal Agroekoteknologi Universitas Sumatera Utara, 2(4), 1426-1432. https://media.neliti.com/media/publications/101546-ID-pemberian-bahan-organik-komposjerami-pa.pdf

8. Pranata, M., \& Kurniasih, B. (2019). Pengaruh pemberian pupuk kompos jerami padi terhadap pertumbuhan dan hasil padi (Oryza sativa L.) pada kondisi salin. Vegetalika, 8(2), 95-107. https://doi.org/10.22146/veg.45907

9. Sukainah, A., Lestari, N., \& Rivai, A. A. (2020). Pemanfaatan Pestisida Alami untuk Mendukung Pertanian Berkelanjutan di Desa Samangki, Kecamatan Simbang, Kabupaten Maros [Conference presentation]. Seminar Nasional Pengabdian Kepada Masyarakat. https://ojs.unm.ac.id/semnaslpm/article/view/19138

10. Simanungkalit, R. D. M., Suriadikarta, D. A., Saraswati, R., Setyorini, D., \& Hartatik, W. (2006). Pupuk Organik dan Pupuk Hayati. Balai Besar Penelitian dan Pengembangan Sumberdaya Lahan Pertanian, Badan Penelitian dan Pengembangan Pertanian http://repository.pertanian.go.id/bitstream/handle/123456789/9394/Pupuk\%20Organik\%20dan\% 20Pupuk\%20Hayati.pdf?sequence $=1$

11. Triyono, A., Purwanto, \& Budiyono. (2013). Efisiensi Penggunaan Pupuk -N untuk Pengurangan Kehilangan Nitrat pada Lahan Pertanian [Conference presentation]. Seminar Nasional Pengelolaan Sumber Daya Alam dan Lingkungan http://eprints.undip.ac.id/40721/1/Ari_Triyono.pdf

12. Wahyuni, S. A. T., \& Asngad, A. (2017). Pemberian Pupuk Organik Cair Limbah Jerami Padi dan Limbah Cangkang Telur Ayam untuk Meningkatkan Kandungan Kalsium Tanaman Sawi (Brassica Juncea, L.) [Conference presentation]. Seminar Nasional Pendidikan Biologi dan Saintek II. https://publikasiilmiah.ums.ac.id/xmlui/handle/11617/9329 